Agro-Science Journal of Tropical Agriculture, Food, Environment and Extension

Volume 11 Number 1 Januarv 2012 nn 37 - 42

ISSN 1119-7455

\title{
TECHNICAL EFFICIENCY OF ENUGU URBAN BROILER FARMERS IN ENUGU STATE, NIGERIA
}

Ume, S.I. Jiwuba, P.D. and Ede, N.O.

Federal College of Agriculture, Ishiagu, Ivo Local Government Area of Ebonyi State, Nigeria

\begin{abstract}
The study measured the level of technical efficiency and among determinants in broiler farmers in Enugu urban of Enugu State, Nigeria using stochastic frontier production function. Multi-stage sampling technique was used to select 120 broiler farmers from which data were collected using well-structured questionnaire and oral interview. The estimated technical efficiency of urban broiler farmers ranged between $88.0 \%$ and $98.0 \%$ with a mean of $95.0 \%$. The educational level, farming experience, access to credit, extension contact and membership of cooperative society were the determinants of technical efficiency of urban broiler farmer. Improving farmers' access to education, credits, among others, would enhance farmers' technical efficiency for the sustainability of urban broiler production.
\end{abstract}

\section{INTRODUCTION}

In most developing countries, agriculture was primarily a rural based activity. But, because of growing demand for food and job, compelled many urban dwellers to embark on urban farming to satisfy their food demands and provide income to better their welfare (Umo, 2005). Urban agriculture in Nigeria, World Bank (1990) was reinforced by the aftermath of structural adjustment programme, including rise in food prices, unemployment and inflation which declined the average real income of both urban and rural dwellers.

In Nigeria, poultry accounts for about $30.28 \%$ of the total livestock production. In terms of production in Africa, Nigeria ranks the highest with a total of 190 million chickens between 2009-2011 (Kughur et al, 2012). Broiler, a sector of poultry constitutes more than $18 \%$ of animal proteins consumed in urban area with more than $28 \%$ also produced in the urban area (FAO, 2006). A host of factors may explain why broiler is endeared to both the producers and consumers, such as superefficient converter of feed to meat, large number of birds requiring small space (Eleke, 2005), marketable at different ages (Agwu and Duru, 2010), ease of operation, gives quickest turnover, the meat is palatable, easily digestible and low production cost per unit relative to other livestock (Ojo, 2004).

However, low production and productivity have characterized this sub sector and in effect limit its role in economic development. Inyang (1995), Ngoka (1998) and Isika, et al. (2007) cited scarcity and high cost of feed, lack of capital, poor breeds of chicks, high cost of drugs and medication, pests and diseases, poor marketing and management problems as limiting factor in attaining selfsufficiency among broiler farmers. Considerable efforts have been directed exclusively on broiler rearing (Omoruoyi et al, 1998; Ngoka, 1998) and marketing (Agwu and Duru, 2010) but information on technical efficiency of broiler production in the study area is lacking.

Technical efficiency is the achievement of maximum potential output from a given inputs under a given technology (Onyenweaku and Effiong, 2006). Estimation of the level of technical efficiency helps to determine if the deviation in technical efficiency from frontier output is due to specific factor or external random factor. Specifically, the objectives of this study were to determine the level of technical efficiency, estimate elasticity and return to scale and the constraints to broiler production.

\section{MATERIALS AND METHODS}

The study was conducted in Enugu urban in Enugu State, Nigeria. Enugu is located within the following coordinates; North $6^{0} 64^{\prime}$ and $5^{0} 59^{\prime} \mathrm{N}$ and $6^{0} 53^{\prime}$ and $5^{\circ} 56^{\prime} \mathrm{E}$. It has temperature range of $28-31^{\circ} \mathrm{C}$, relative humidity of $58-62 \%$ and annual rainfall of $1200 \mathrm{~mm}$ - 2500mm (Ike, 2009). Enugu with 
coal deposit was the headquarter of former eastern region during colonial era (1957 1960), later East Central State (1967 - 1973). Enugu later became the capital of former Anambra State (1976 - 1995) and presently Enugu State (1995 - till date). Enugu State is inhabited by people from various tribes and races within and outside Nigeria including, public/civil servants, businessmen and women, company workers, farmers, artisans and petty traders. Enugu urban has high population figure of 1.8 million people (NPC, 2007). This could be because of many civil servants in the neighbouring states around Enugu State still operate from the metropolitan and as well as lots of unemployed youths seeking for job in the federal and state ministries, parastatals and private business.

Multistage random sampling technique was employed in the selection process. In the $1^{\text {st }}$ stage, six (6) layouts (Ogui New Layout, Achara Layout, Abakpa, Uwani, Gariki and Coal Camp) out of 10 were randomly selected. In the $2^{\text {nd }}$ stage, from the lists of broiler farmers provided by agricultural extension agent and local leaders, twenty (20) broiler farmers were selected from each of the layouts. This makes a total of one hundred and twenty boiler farmers for the detailed study. Data were collected using well structured questionnaire and oral interview to collect information bothering on socioeconomic characteristics of the farmers and prices of inputs and outputs. Descriptive statistics such as percentage response was used to determine the farmers' socioeconomic characteristics and the constraints to broiler production. The technical efficiency was analysed using stochastic frontier production function model. The theoretical framework of the stochastic frontier production is specified as follows:

$$
\begin{aligned}
& Y_{i}=f\left(X_{1 i} \beta \exp \left(V i-U_{1}\right), 1=1,2 n\right. \\
& \begin{array}{llll}
\ldots & \ldots & \ldots
\end{array}
\end{aligned}
$$

Where $Y_{i}=$ output of the $i^{- \text {th }}$ farm, $X_{i}=$ vector of input quantities used by the $i^{\text {-th }}$ farm, $\beta=$ is vector of unknown parameters to be estimated, $\mathrm{F}$.) represents an appropriate function (e.g. Cobb Douglas, translog etc). The term $V_{i}$ is a symmetric error which accounts for random variation in output due to the factors beyond the control of the farmers e.g weather, diseases outbreak, measurement error while the term $U_{1}$ is the non-negative random variable representing inefficiency in production relative to the Stochastic frontier. The random error, $\mathrm{V}_{\mathrm{i}}$ is assumed to be independently and identically distributed as $\mathrm{N}\left(0, \sigma^{2}\right)$ independent of the $U_{i}$, which are assumed to be non-negative truncation of the No, , $\left.{ }^{2}\right)$ distribution. The stochastic frontier was independently proposed by Aigner et al. (1977) and Meeusen and Vander Broeck (1977). Technical efficiency of an individual farmer is defined in terms of the ratio of the observed output to the corresponding frontier output, given available technology (Onyenweaku, and Effiong, 2006).

\section{Technical efficiency $\mathrm{TE}=\mathrm{Y}^{*} / \mathrm{Y}=\mathrm{F}\left(\mathrm{x}_{1} \beta\right) \exp \left(\mathrm{V}_{1}-\right.$} Ui) $\mathrm{F}\left(\mathrm{X}_{1 \mathrm{i}} \beta\right) \exp (\mathrm{V})=\exp \mathrm{Vi} \ldots$

Where $\mathrm{Y}=$ observed output and $\mathrm{Y}^{\wedge}=$ the frontier output. The parameter of the stochastic frontier production function are estimated using maximum likelihood method.

\section{Empirical Model}

For this study, the production technology of broiler farmers in Enugu urban is assumed to be specified by the Cobb Douglas production function defined as follows: $\ln Q=\beta_{0}+\beta_{1} \ln X_{1}+\beta_{2} \ln X_{2}+\beta_{3} \ln X_{3}+$

$\beta_{4} \ln \mathrm{X}_{4}+\beta_{\mathrm{n}} \ln \mathrm{X}_{\mathrm{n}}+\mathrm{V}_{1} \mathrm{U}_{1} \quad \ldots \quad \ldots$

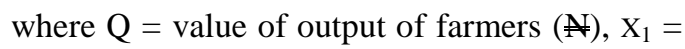
broiler chicks (No), $\mathrm{X}_{2}=$ feeds use $(\mathrm{kg}), \mathrm{X}_{3}=$ labour inputs (manday), $\mathrm{X}_{4}=$ drug and medication (litres), $\mathrm{X}_{5}=$ water required (liters), $\mathrm{X}_{6}=$ capital depreciation $(\#), \mathrm{V}_{\mathrm{i}}=$ Error term not under the control of the farmer, $\mathrm{U}_{\mathrm{i}}=$ error term under the control of farmer, $\beta_{0}=$ intercept, $\beta_{1}-\beta_{2}=$ parameters to be estimated.

The socioeconomic determinants of the technical inefficiency was simultaneously modelled and defined by

$$
\mathrm{U}_{\mathrm{i}}=\mathrm{a}_{0}+\mathrm{a}_{1} \mathrm{~m}_{1}+\mathrm{a}_{2} \mathrm{~m}_{2}+\mathrm{a}_{3} \mathrm{~m}_{3}+\mathrm{a}_{4} \mathrm{~m}_{4}+
$$

$\mathrm{a}_{5} \mathrm{~m}_{5}+\mathrm{a}_{6} \mathrm{~m}_{6}+\mathrm{a}_{\mathrm{n}} \mathrm{m}_{\mathrm{n}}+\mathrm{e} \quad \ldots \quad \ldots$

Where $\mathrm{m}_{0}=$ intercepts; $\mathrm{m}_{1}-\mathrm{m}_{5}=$ coefficient to be estimate; $a_{1}=$ age of the farmer $(y r s) ; a_{2}=$ farm size (No); $a_{3}=$ household size (No); $a_{4}=$ educational level (yrs); $a_{5}=$ farming experience (yrs); $\mathrm{a}_{6}=$ access to credit $(\mathrm{N}) ; \mathrm{a}_{7}=$ extension contact $(\mathrm{No}) ; \mathrm{a}_{8}=$ membership of cooperative (dummy).

To estimate the model and separate inefficiency $\mathrm{U}_{\mathrm{i}}$, some assumptions about the distribution, i.e., $\mathrm{V}_{1} \mathrm{~N}\left(\mathrm{O}, \alpha^{2}\right)$ while $\mathrm{U}_{\mathrm{i}}$ has a half normal distribution i.e. $\mathrm{U}_{1}=\left(\mathrm{O}, \alpha^{2}\right)$. The estimate for all the parameters of the Stochastic Frontier Function and inefficiency wee simultaneously obtained using the program frontier version 4.1 (Coelli, 1996). 


\section{RESULTS AND DISCUSSIONS}

The mean statistics of urban poultry farmers are shown in table I. On the average, a typical urban broiler farmer was 37.2 years old with 10.3 years of education, 10 years of urban broilers production experience with average stock size of 21.4 birds. The mean household size was 6 persons with average annual income of $\$ 62,284$ and mean output of 420 birds for four months.

The maximum livelihood estimates $(\mathrm{M} / \mathrm{E})$ of the stochastic frontier production parameters for urban broiler farmers is presented in table 2. The total variance $(\sigma)$ was 0.8701 which was significantly different from zero at $1 \%$ level. This implies goodness of fit of the model and the correctness of the specified distribution assumption of the composite error term. The variance ratio parameter was estimated at 0.6027 which was also statistically significant at $1 \%$ probability level, indicating that $60.2 \%$ of the total variation in broiler output was due to technical inefficiency.

Table 1: Mean socioeconomic statistics of Enugu urban broiler farmers

\begin{tabular}{ll}
\hline Variable & Mean value \\
\hline Age of urban broiler farmer (yrs) & 37.2 \\
Educational level (yrs) & 10.3 \\
Farming experience & 10 \\
Farm size (ha) & 21.4 \\
Household size & 6 \\
Annual income (N) & $\mathrm{N} 62,284$ \\
Output & 420 \\
\hline Source: Field Survey, 2010 &
\end{tabular}

The coefficient of the broiler chick feed, labour inputs and drug and medication had the desired positive signs and were statistically significant at $1.0 \%$ probability level. The implication is that the more broiler chicks used, the more the mature broiler's accruing to the farmers, ceteris paribus. The estimated coefficient of feed was negative and statistically significant at $1 \%$ probability level. This infers that one percent increase in feed used, 1 lead to 2.067 percent decrease in total farm income. The coefficient (0.2536) of labour input was positive and statistically significant at $1 \%$ probability level. This implies that one percent increase in labour input resulted to 0.2536 percent increase in the revenue of the broiler farmer. Drug and medication had positive coefficient $(0.0042)$ and significant at $5 \%$ risk levels, which implies that 5 percent increase in drug and medication increased the revenue of farmers through reduction in the mortality rate of the birds by 0.0042 percent. The estimated coefficient (0.0145) of water use was positive and statistically significant at $10 \%$, implying the direct relationship between the variable and the farmers' output.

\section{Table 2: Estimated stochastic production function for broiler farmers in Enugu urban}

\begin{tabular}{lcccc}
\hline Production Factor & Parameter & Coefficient & $\begin{array}{c}\text { Standard } \\
\text { error }\end{array}$ & t-ratio \\
\hline Constant term & $\beta_{0}$ & & & \\
Broiler chicks & $\beta_{1}$ & 2.319 & 0.437 & $5.425^{* * *}$ \\
Feed use & $\beta_{2}$ & -2.067 & 0.549 & $-3.766^{* * *}$ \\
Labour input & $\mathrm{B}_{3}$ & 0.2536 & 0.0681 & $3.7243^{* * *}$ \\
Drug and medicine & $\beta_{4}$ & 0.0042 & 0.0018 & $2.326^{* *}$ \\
Water requirement & $\beta_{5}$ & 0.0145 & 0.0075 & $1.9266^{*}$ \\
Capital & $\beta_{6}$ & 0.0520 & 0.0227 & -2.2916 \\
depreciation & & & & \\
Diagnostic statistics & & & & \\
Total variance & $\mathrm{q}^{2}$ & 0.8701 & & \\
Variance ratio & $\gamma$ & 0.6027 & & \\
Likelihood ratio & & & & \\
test & & & \\
Los log likelihood & & & \\
\hline Source: Field Survey, 2010 & & & \\
$* * *=\quad$ significant at $1 \%$ & & & \\
$* * * \quad$ significant at $5 \%$ & & & \\
$* * \quad$ significant at $10 \%$ & &
\end{tabular}

The maximum likelihood estimate of the determinants of technical inefficiency of urban broiler farmers is presented in table 3 . Educational level showed positive relationship with technical efficiency and statistically significant at $1 \%$ risk level. This result is consistent with Okoye and Onyenweaku (2007) who opined that educated farmers are expected to be more receptive to improved farming techniques. Farming experience was positive and significant at $1 \%$. This agrees with apriori expectation. Farmers with long years of farming experiences tend to combine their resources better in an optimal manner. Ewuziem et al. (2010) finding confirmed this assertion. Credit access was negative and significant at $5 \%$ risk level, which is contrary to apriori expectation. The diversion of loan to non-agricultural uses is the critical reason for the behaviour of the variable. Onyenweaku et al (2010) confirmed to this finding. Extension contact was positive and significant at 5\%. Onyenweaku and Nwar (2005) finding is in confirmation to this assertion. This implies that the more extension contact, the broiler farmer has the more likelihood of his/her achieving decreased technical inefficiency. Membership of organization was positive and significant at $10 \%$ probability level. The effect of membership organization has been variously found to be positive with technical efficiency (Dung et al.,, 2010; Eze and Akpa, 2010). 
The distribution of the technical efficiency estimates obtained from the stochastic frontier is presented in table 4 . The result shows that $83.3 \%$ of the urban broiler farmers operated at efficiency level greater than $80 \%$. The mean technical efficiency of the farmer is $95 \%$. This figure compares favourably with $93 \%$ reported by Eze and Akpa (2010). In short run, there is opportunity for increasing broiler production in Enugu urban by $5 \%$, by adopting innovations employed by the best practices in broiler farming. The maximum technical efficiency is $98 \%$. The level of technical efficiency in this study implies that opportunities still exist for increasing productivity and income through efficient use of resources among urban broiler farmers in Enugu urban.

The implication of the mean technical efficiency (95\%) is that an average broiler farmer requires $30.6 \%$ cost saving to attain the status of the most efficient broiler farmer among the sampled best 10 category while the least farmer would need $10.2 \%$ cost saving to become the most efficient urban broiler farmer among the worst 10 sampled farmers.

The elasticity and return to scale for broiler production in Enugu urban is shown in table 5. The regression coefficient in the Cobb Douglas stochastic production frontier function are the elasticities and their sums indicate the return to scale (Hazarika and Subramanian, 1999). The return to scales (production elasticities) has a function coefficient of 1.4782. This implies that broiler production farmers production plan is elastic, hence the farmers are in stage two of production function phase. This could be as a result of high and positive coefficient of feed with low and positive coefficient of depreciation. This implies that broiler farmer in Enugu urban optimally utilize their scare resource, particularly feed in their production process.

Table 3: Estimated determinant of technical inefficiency in broiler farmers in Enugu urban

\begin{tabular}{|c|c|c|c|c|}
\hline Determinants & Parameter & Coefficient & $\begin{array}{l}\text { Standard } \\
\text { Error }\end{array}$ & t-ratio \\
\hline Age of farmer & $a_{1}$ & -0.0099 & 0.0394 & -0.2512 \\
\hline Farm size & $\mathrm{a}_{2}$ & 0.0928 & 0.0636 & 1.4148 \\
\hline Household size & $\mathrm{a}_{3}$ & 0.0143 & 0.0049 & 2.9184 \\
\hline $\begin{array}{l}\text { Educational } \\
\text { level }\end{array}$ & $\mathrm{a}_{4}$ & 2.9577 & 0.4013 & $7.36 * * *$ \\
\hline Farming experience & $a_{5}$ & 0.6912 & 0.0912 & $7.5759 * * *$ \\
\hline Access to credit & $\mathrm{a}_{6}$ & -0.1023 & 0.1963 & 0.5211 \\
\hline Extension contact & $a_{7}$ & -0.0520 & 0.0227 & $-2.2916 * *$ \\
\hline $\begin{array}{l}\text { Membership of } \\
\text { organisation }\end{array}$ & $\mathrm{a}_{8}$ & 0.0145 & 0.0075 & $1.9266^{*}$ \\
\hline 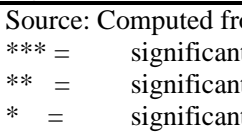 & vey, 2010 & & & \\
\hline
\end{tabular}

Table 4: Distribution of technical efficiency indices of broiler farm in Enugu urban

\begin{tabular}{cccc}
\hline Technical Indices & Efficiency & Frequency & Percentage \\
\hline 0.00 & 0.20 & 0 & 0 \\
0.21 & 0.40 & 0 & 0 \\
0.41 & 0.60 & 0 & 16.7 \\
0.61 & 0.80 & 20 & 83.3 \\
0.81 & 1.00 & 100 & 100.0 \\
\hline Total & 120 & & \\
\hline Maximum technical efficiency $=0.98$ & & & \\
Minimum technical efficiency $=0.88$ & & & \\
Mean technical efficiency $=0.95$ & & & \\
Mean of best 10 farmers $=0.05$ & & & \\
Mean of worst 10 farmers $=0.88$ & &
\end{tabular}

Table 5: Elasticity and return to scale for broiler production in Enugu urban

\begin{tabular}{lc}
\hline Production inputs & Elasticity \\
\hline Feeds & 1.3471 \\
Broiler chicks & 0.0682 \\
Labour & 0.0421 \\
Farm size & 0.0077 \\
Depreciation & 0.0131 \\
Return to scale & 1.4782 \\
\hline Source: Field Survey data, 2010
\end{tabular}

Source: Field Survey data, 2010 
Table 6: Constraints to broiler production

\begin{tabular}{lc}
\hline Constraints & Percentage \\
\hline High cost of medication & 68 \\
Problems of adulterated drug & 62 \\
Scarcity of raw material & 48 \\
Poor breeds & 82 \\
Unavailability of drug and vaccine & 47 \\
High mortality & 72 \\
Low patronage during glut & 63 \\
Bird flu & 14 \\
High cost of feed & 65 \\
Poor access to credit & 86 \\
Pests and diseases & 54 \\
\hline
\end{tabular}

Furthermore, on the individual production input elasticity showed that change in the broiler chick, labour, size of farm land and capital employed by 1 unit brought about a change in opposite direction of $0.0682,0.0421$, 0.0077 and 0.0131 in the output of broiler respectively. In the same way, a unit change in feeds intake brought about a change in opposite direction of 1.3471 in the output of broiler

Table 6 shows the constraints to broiler production. Most of the farmers interviewed encountered the problem of poor access to credit. This could be emanated from the inability of the farmers to provide the necessary collaterals as demanded by lending agencies and as well as high interest rate of loan (Ume et al, 2008). $82 \%$ of the farmers complained of poor breeds of broiler chicks. Ngoka (1998) reported that the poor performance of these breeds are highly economical, as not only missing the market target but also wastage of space, labour and finance with minimal profit. $72 \%$ of the farmers reported high mortality of broiler especially during transportation and rearing. The consequence of high mortality is reduced income which is tantamount to low savings and low investment (Kughur, et al, 2012).

\section{CONCLUSION AND RECOMMENDATIONS}

The result of this study showed that the technical efficiency of broiler farmers in Enugu urban of Enugu State is high. The individual levels of technical efficiency ranged between $88 \%$ and $98 \%$ with mean of $95 \%$, this implies that there are opportunities for improving the productivity and income of the broiler farmers in Enugu urban by increasing their farm level resource use efficiency.

The important determinants of technical efficiency among broiler farmers were; educational level, farming experience, access to credit, extension contact and membership of organization. To address inefficiency in broiler producers, the following policy options are suggested: i. Improving farmers' access to education through adult education programme and mass mobilization.

ii. Access to credit through micro-credit institutions and other lending organization

iii. Farmers are advised to form cooperative to ensure easy access to credit acquisition, improved inputs and capacity building.

iv. Experienced farmers and even new entrants are encouraged into broiler business by providing them with essential and improved productive inputs at reduced cost.

v. Extension contact with farmers should be encouraged through adequate motivations and provision of mobility.

\section{REFERENCES}

Agwu, N. and Duru, E. (2010): Marketability and profitability among broiler farmers in Imo State. Nigeria Agricultural Journal 41(2): 133 - 138.

Aigner, D; Lovel, C.A.K and Schmdit, P. (1977): Formulation and estimation of stochastic frontier production model. Journal of Econometric 6: 21 - 27.

Coelli, J. T. (1996). "A guide to frontier 4.1 computer program for stochastic frontier production and cost function estimation". Mimeo Development of econometrics University of New England Arimidate Australia.

Dung, A.E; Akinkpelu, O.A and Asumugha, G.N. (2010): Technical efficiency of Hausa potato production in southern Kaduna State, Nigeria. Nigeria Agricultural Journal 41(1): 53 - 57.

Eleke, A. (2005): Broiler business and poverty reduction. Sun newspaper, $24^{\text {th }}$ April 2005.

Ewuziem, J.E; Onyenobi, V.O. and Ironkwe, A.C. (2010): Technical efficiency of pig farmers in Imo State, Nigeria. A translog stochastic frontier production 
function approach. Nigeria Agricultural Journal 41(2): 138 - 141.

Eze, C.I. and Akpa, C.E. (2010): Analysis of technical efficiency of National Fadama II facility on arable crop farmers in Imo State, Nigeria. Nigeria Agricultural Journal 41(1): 108 - 114.

FAO (2006): FAOSTAT. Food and Agriculture Organization, Database result.

Hazarika, C. and Subranian, S.R. (1999): Estimation of technical efficiency in the stochastic frontier production function model. An application to the tea industries in Asarn. Journal of Agricultural Economics 54(2): 201 211.

Ike, T. K. (2009). Determinant factors to vegetable production in Enugu Urban of Enugu State. International Journal of Agriculture and Biology, 6(1): 6-11.

Inyang, E.U. (1995): Factors affecting broiler production in Akwa Ibom State. Higher National Diploma in Agricultural Extension and Management.

Isika, M.A; Idiong, Etuk, I.C. and Agom, D.J. (2007): Resource use of efficiency of broiler enterprises in Cross River State. International Journal of Poultry Science 6(1): 23-20.

Kughur, T.C; Dandu, S. and Onu, D.E. (2012): Factors affecting adoption of poultry innovation by rural farmers in Otukpo L.G.A., Benu State, Nigeria. Proceedings of the $45^{\text {th }}$ annual conference of the Agricultural Society of Nigeria (ASN).

Meeusen, N. and Van der Broeck, J. (1977): Efficiency estimation from Cobb Douglas production function with composite error. International Economic Review 18(2): $77-83$.

National Population Commission (NPC) (2006) Abuja, Nigeria.

Ngoka, D.A. (1998): Nigeria manual of practical poultry production. National Root Crops Research Institute, Umudike, Umuahia.
Ojo, S.O. (2003): Improving labour productivity and technical efficiency in food crop production. A pancreas for poverty reduction in Nigeria. Food Agriculture and Environmental Journal 2(2): 227 231.

Ojo, S.O. (2004): Productivity and technical efficiency of poultry egg production in Nigeria. International Journal of Poultry Science 2(6): 459 - 464.

Omoruyi, S.A; Orhue, U.X. and Akerobo, A.A. (1999): Prescribed agricultural science for senior secondary schools. Revised edition, Idodo Ume Publishers Ltd.

Onyenweaku, C.E. and Nwaru, J.C. (2005): Application of stochastic frontier production function to the measurement of technical efficiency in food production in Imo State, Nigeria. Nigeria Agricultural Journal 37(1): 37 $-41$.

Onyenweaku, E.C. and Effiong (2006): Technical efficiency in pig production in Akwa Ibom State, Nigeria. A paper presented at the $40^{\text {th }}$ conference of Agricultural Society of Nigeria held at National Root Crop Research Institute, Umudike.

Onyenweaku, E.C; Okoye, B.C. and Okorie, K.C. (2010): Determinant of fertilizer adoption by rice farmers in Bende local government area of Abia State, Nigeria. Nigeria Agricultural Journal 41(2): 1 6.

Ume, S.I; Okoronkwo, M.O. and Ulo, V.E. (2008): Adoption of improved rice production technology by farmers in Anambra State. Ebonyi Technology and Vocational Journal 4(2): 17 - 21.

Umo, G. (2005): Resource use efficiency in urban agriculture. An application of stochastic frontier function. International Journal of Agriculture and Biology 1: $33-44$.

World Bank (1990): World tables 1989 - 1990 press edition, John Hopkins University Press. 